
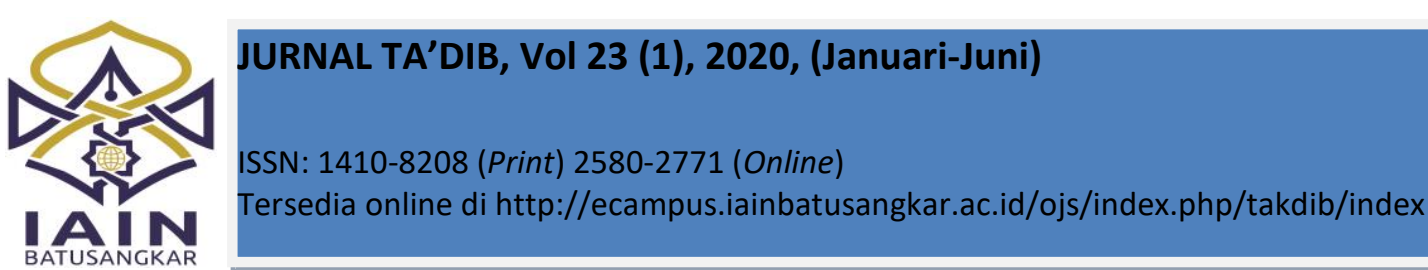

\title{
Students' Perception on the Implementation of Basic Physics Practicum Guide on Mobile Learning
}

\section{Darmaji \\ Universitas Jambi, Indonesia \\ E-mail: darmaji@unja.ac.id}

Dwi Agus Kurniawan*)

Universitas Jambi, Indonesia

E-mail: dwiagus.k@unja.ac.id

\section{Astalini}

Universitas Jambi, Indonesia

E-mail: astalinizakir@unja.ac.id

\section{Utari Prisma Dewi}

Universitas Jambi, Indonesia

E-mail: utariprismadewi@gmail.com

*) Corresponding Author

\begin{abstract}
Abtract: This study aims to investigate at students' perceptions on basic physics practicum guides on mobile learning. This research was a descriptive study involving 117 students with 59 physics education students and 58 chemistry ones. The instruments were questionnaires and semi-structured interviews intended to strengthen the quantitative data. The data collection was carried out by distributing questionnaire to the physics and chemistry education students who have conducted physics practicum using a mobile-based guide. Then interview was conducted only to those willing to be interviewed. The data were analyzed with descriptive statistics to determine students' perceptions on mobile-based practicum guides.. The results showed that the practical learning guide based on mobile learning is feasible to use with the results of the perception of physics education included in both categories with a frequency of $38(64.4 \%)$ and for chemical education perceptions also in the good category with a frequency of 28 (48.3\%). The data were supported by interview results showing that students are more interested and enthusiastic in conducting practical work because they used mobile-based guides.
\end{abstract}

Keywords: Perception, Practical Guides, Mobile Learning.

\section{INTRODUCTION}

$\mathrm{P}$ hysics is a part of the science that has the nature of a process, products, and values (Edie, 2018; Kurniawan \& Parasdila, 2018). Physics is a science that is in contact with everyday life and with scientific formulas and concepts. According to Young, et al (2002), "there are two reasons why we have to study physics, first, one of the most basic sciences is physics, secondly all the science of technology and also engineering is the basis of learning". Maksum et al., (2017) propose problem solving can be carried out by guiding students to apply the existing knowledge by themselves. Basic physics is a compulsory subject in the Physics Education study program at the University of Jambi and weighs 4 SKS (3 SKS face to face and 1 SKS practicum). Basic Physics Practicum aims to help students solve natural phenomenon problems and practice science process skills (KPS) for students. Munayyaroh (2013) states "practicum as a laboratory activity that has a role in supporting the success of the science learning process". Practicum activities are methods used to clarify the material that has been learned. Practicum is teaching that aims to make students clearly prove what is obtained in theory (Kustijono, 2018). In order for practicums to be carried out, clear and easy, practical guides are needed for use.

The practicum guide is used as a reference for practicum both for students and teaching assistants. The initial assignment or preliminary task is a way to study the experimental guide and related material before practicum begins. The basic Physics practicum guide used today is a guide that 
can train students' science process skills. Practical activities require KPS owned by students such as: formulating hypotheses; formulate a problem; identifying variables and analyzing data; and draw conclusions so as to find knowledge in achieving learning competence (Misbah, 2018; Ozdemir \& Dikici, 2016). Student science process skills are important skills to develop in education (Dasna, 2018). Process skills are also considered a scientific method used to train students' steps in finding things through activities experimental (Darmaji, Kurniawan, DA, Parasdila, H., \& Irdianti, 2018). The observed aspects of science process skills (KPS) include observing, predicting, measuring, using tools, doing work, interpreting data, communicating and concluding. Science process skills are highly demanded to be possessed by students in the learning process (Hartini \& Qohar, 2018). Because understanding concepts and KPS is an important thing to have, problems arising in understanding concepts and KPS experienced by these students must be dealt with as soon as possible by a physics lecturer (Yadaeni, Kusairi, \& Malang, 2018). The use of basic physics practicum guides that are able to train student KPS greatly helps students in the process of carrying out practical work.

In addition, practicum guides can train students' science process skills. The use of media can also help students in the learning process. According to Uno (2016) the learning process requires an interesting and enjoyable learning media as a source of student independent learning. A media and practical guide can overcome the limitations in the implementation of practicum, so students get their learning experience (Limatahu, 2017). Media is a communication channel. Derived from the Latin word meaning "between," this term refers to something that carries information (Heinich, Molenda, \& Russell, 2002). Media are forms of communication both in printed form and in audiovisual form and its equipment. Media that is able to provide precise information between the recipient of information and the provider of information is good media (Pratama, Ulfa, \& Kuswandi, 2013; Zulika et al, 2018 ). Learning media that are widely used today is smartphones. They are used not only for communication devices but also used as learning media (Hasanah, Hasani, Fatah, Sari \& Romdani, 2018). As time develops, both in the field of media technology and the media used for learning will also develop. That way this is very supportive of the learning process (Ta,Abed, \& Ahmad, 2017).

In line with the industrial revolution 4.0, various technologies have developed widely. The concept of Industry 4.0 assumes blurring the differences between the work of people and the work of machines (Ślusarczyk, 2019). The use of technology in the learning process in the current era is mushrooming everywhere, one of which is-based learning media smartphone. Technology is widely used as a learning medium, so it is very supportive of the learning process. According to Asrial (2019), currently, education in Indonesia is much influenced by the industrial revolution 4.0, namely technology, information and communication (ICT). In the field of education, the use of technology is centered on improving the quality of learning. As a result, it can improve the quality of education (Prasojo \& Riyanto, 2011). The development of technology grows very fast and many gave rise to a variety of new applications, including the development of smartphones. At present Smarphone has become a mandatory requirement among students. According to Cahyana et al., (2017) the development of technology can also be used as a learning medium that can support the learning process. However, the use of education is still very lacking. In 2016 the Indonesian Internet Network Providers Association (APJII) conducted a survey with the results showing that $89.7 \%$, the largest internet users in Indonesia were students. The problem that needs to be addressed by educators is to direct students to better use the internet in the realm of education (Saifuddin, 2017). An example that still uses 
the internet a little is a basic physics course. Over the last few decades, information and communication technologies have improved greatly and the use of computers has become more widespread (Vyas \& Nirban, 2014). Through various advantages in the use of technology owned, one of which is computer technology has inspired many experts in the field of education to empower it on a broader scale, so that the process of use is not limited to learning, but also becomes the main tool in the administration of education (Prawiradilaga, Ariani, \& Handoko, 2013). Learning media using technology are no longer heard at this time. Based on this reason, the researchers are interested to investigate the students' perception of the Basic Physics Practicum guide based on mobile learning.

Perception is a process of students interpreting, evaluating, accepting, giving opinions and testing the data and sensory responses to what they see (Slameto, 2010). Through the five senses that is like seeing is very closely related to the perception of students after the object concerned sees. Perception students usually occur during the learning process in class both perceptions of learning materials, learning models used and the media used. The influence on the social environment in which the individual lives can cause someone's perception to arise (Fitriana, Utaya, \& Budijanto 2016; Cahyanti, Sinaga, \& Amsor, 2018). Consequently, the use of mobile learning can help students become better at learning. Innovative mobile learning makes the learning process easier and more attractive so it is effective for learning (Huang, 2016; Yang, Hwang, \& Sung, 2018).

According to Wahyuni, (2011) the research team observed the course of the learning process in the form of practicum using observation sheets. Observation Sheet and Basic Physics Practicum Guide used today is still in the form of hard copy. The use of observation sheets and practical guides is less effective and efficient so to make it easier it is used by the media to support the learning process. In addition to being less effective and efficient, the current practical guide also consumes a lot of paper so as to minimize the use of paper, the solution is to use observation sheets and basic physics practicum guides in the form of mobile learning. Since at this time students in general have used a smartphone so to support the science process skills students can use observation sheets and basic physics practicum guides based on mobile learning that can be used anytime and anywhere so that students can prepare themselves in advance for practical activities. Therefore, to facilitate the implementation of practicum and increase students 'insights, researchers consider looking at students' perceptions of the application of basic physics practicum guides based on mobile learning.

\section{METHOD}

This research was a descriptive research. Descriptive research is a research conducted in order to find out the value of independent variables, either one or more variables without making comparisons (Sugiyono, 2013). In this study, students' perceptions were viewed in terms of perceptual variables towards the basic physics practicum guide based on mobile learning at FKIP Jambi University. This study involved 117 majors consisting of 59 Physics Education Study Program students and 58 Chemistry Study Program students.

Data collection used perception questionnaire guided by Likert scale using categories of Very Not Good, Not Good, Enough, Good, and Very Good (Batubara, 2016). In addition to using questionnaire perception data collection, interviews was also used to strengthen quantitative data. The questionnaire items of students' perceptions of the basic physics practicum guide based on mobile learning were 10 statements with each positive and negative statement having 5 answer options. Student responses expected from the questionnaire in the form of answers Good or Not Good by giving a score for each positive statement as follows: Very Good=5, Good=4, Enough=3, Not Good=2, Very Not Good=1. Scoring for each negative statement is as follows: Very Good 
=1, Good=2, Enough=3, Not Good=4, Very Not Good=5. The level of students' perception categories on basic physics practicum guidelines can be seen in the following table 1:

Table 1. The level of student perception categories

\begin{tabular}{|c|c|c|}
\hline No. & Category & Score Interval \\
\hline 1. & Very Not Good & $20,0-36,0$ \\
\hline 2. & Not Good & $36,1-52,0$ \\
\hline 3. & Enough & $52,1-68,0$ \\
\hline 4. & Good & $68,1-84,0$ \\
\hline 5. & Very Good & $84,1-100,1$ \\
\hline
\end{tabular}

Data analysis techniques using descriptive statistics obtained mean (M), median (Mo), maximum value and minimum value on perception and interview using Miles \& Huberman with the stages of reducing data, displaying, and conclusion (Miles, 1994).

\section{RESULTS AND DISCUSSION}

The results of students' perceptions of education in mathematics and natural sciences to e-module in physics practicum can be seen in table 2 .

Table 2. Description of students' perceptions on basic physics practicum guides based on mobile learning

\begin{tabular}{|c|c|c|c|c|c|c|c|c|c|}
\hline \multicolumn{4}{|c|}{ Classification } & \multirow{2}{*}{ Mean } & \multirow{2}{*}{ Median } & \multirow{2}{*}{ Mode } & \multirow{2}{*}{ Min } & \multirow{2}{*}{ Max } & \multirow{2}{*}{$\%$} \\
\hline Department & Interval Score & Category & total & & & & & & \\
\hline \multirow{5}{*}{ Physics } & $20.0-36.0$ & Very Not Good & 0 & \multirow{5}{*}{71.1695} & \multirow{5}{*}{74.0000} & \multirow{5}{*}{$72.00^{\mathrm{a}}$} & \multirow{5}{*}{49.00} & \multirow{5}{*}{91.00} & 0 \\
\hline & $36.1-52.0$ & Not Good & 3 & & & & & & 5.1 \\
\hline & $52.1-68.0$ & Enough & 13 & & & & & & 25.4 \\
\hline & $68.1-84.0$ & Good & 38 & & & & & & 64.4 \\
\hline & $84.1-100.0$ & Very Good & 3 & & & & & & 5.1 \\
\hline \multicolumn{3}{|c|}{ Total } & 59 & & & & & & 100 \\
\hline \multirow{5}{*}{ Chemistry } & $20.0-36.0$ & Very Not Good & 0 & \multirow{5}{*}{70.3621} & \multirow{5}{*}{71.5000} & \multirow{5}{*}{$76.00^{\mathrm{a}}$} & \multirow{5}{*}{49.00} & \multirow{5}{*}{85.00} & 0 \\
\hline & $36.1-52.0$ & Not Good & 1 & & & & & & 1.7 \\
\hline & $52.1-68.0$ & Enough & 24 & & & & & & 41.4 \\
\hline & $68.1-84.0$ & Good & 28 & & & & & & 48.3 \\
\hline & $84.1-100.0$ & Very Good & 5 & & & & & & 5.1 \\
\hline \multicolumn{3}{|c|}{ Total } & 58 & & & & & & 100 \\
\hline
\end{tabular}

Table 2 demonstrates the description of students' perception on the basic physics practicum guide based on mobile learning from 117 students consisting of 59 Physics Education students was good with a percentage of $64.4 \%$ and a mean of 71.16 , median 74.00, 72.00 mode, min 49.00, and max 91.00. while Chemistry Education was in the good category with a percentage of $48.3 \%$ and a mean of 70.36 , a median of 71.50 , mode 76.00 , min 49.00 and $\max$ 85.00 .

Furthermore, to see the level of students' perception of the basic physics practicum guide based mobile learning in physics Education consisting of 59 students can be seen in table 4. However, to see the level of students' perception of the Basic Physics Practicum guide based on mobile learning in Chemistry Education consisting of 58 students can be seen in table 3 .
Table 3. Physics Education student perception to the Basic Physics practicum guide based on mobile learning

\begin{tabular}{ccccc}
\hline No & Interval Score & Category & F & $(\%)$ \\
\hline 1 & $20.0-36.0$ & Very Not Good & 0 & 0 \\
2 & $36.1-52.0$ & Not Good & 3 & 5.1 \\
3 & $52.1-68.0$ & Enough & 15 & 25.4 \\
4 & $68.1-84.0$ & Good & 38 & 64.4 \\
5 & $84.1-100.0$ & Very Good & 3 & 5.1 \\
\hline & Total & & 59 & 100 \\
\hline
\end{tabular}

Table 3 shows the perception of Physics Education students towards the basic physics practicum guide based on mobile learning as many as 38 students were in the good category with a percentage of $64.4 \%$, and 15 students were in the sufficient category with a percentage of $25.4 \%$.

Table 4. Chemistry students' perceptions about Basic Physics Practicum Guide based on mobile learning

\begin{tabular}{ccccc}
\hline No & Interval Score & Category & F & $(\%)$ \\
\hline 1. & $20.0-36.0$ & Very Not Good & 0 & 0 \\
2. & $36.1-52.0$ & Not Good & 1 & 1.7 \\
3. & $52.1-68.0$ & Enough & 24 & 41.4 \\
4. & $68.1-84.0$ & Good & 28 & 48.3 \\
5. & $84.1-100.0$ & Very Good & 5 & 5.1 \\
\hline \multicolumn{7}{r}{} & Jumlah & & 58 & 100 \\
\hline
\end{tabular}

Table 4 shows the chemistry education student's perception of the basic physics 
practicum based on mobile learning as many as 28 students in the good category with a percentage of $48.3 \%$, and 24 students are in the sufficient category with a percentage of $41.4 \%$.

Based on the results of these data, it was found that Physics Education students had better perception than Chemistry Education students' perception of the basic physics practicum guidelines based on mobile learning. The difference in the perception of Physics Education students was higher than the Chemistry Education students' perceptions of the Basic Physics Practicum guide based on mobile learning because when filling in the questionnaire, the perception of responses from chemistry students was still doubtful. Whereas more Physics Education students answered that they agreed with the use of basic Physics Practicum guides based on mobile learning.

Although Physics Education students have better perceptions than Chemistry students' perceptions of basic physics practicum guidelines based on mobile learning, in fact Physics Education students also have bad perceptions with a greater percentage than Chemistry Education students. Based on the interview, Physical Education students tend to be difficult to focus only on learning when using their smartphones. They were told that learning is done through their smartphones sometimes uncontrolled and unsystematic. When they want to dig up information on students tend to stray from the main topic for the curiosity of students. Not only that, but some students also recognize that they cannot ignore the incoming message from their social media so that the use of smartphones in learning more sometimes confiscate their time on social media is not the lesson. While the Chemistry Education students forcefully argued that they could divide their time to stay focused on the topic of their lesson and solve the problems they faced by looking for information together with their peers. They realize that the use of smartphones actually gives them ease in acquiring knowledge for smartphones equipped with various advanced features (applications). They realized that the applications are in use simultaneously (collaborated).

Based on interviews obtained, students like learning media using smartphones (Android). This is because students consider their use to be more practical, accessible anywhere and at any time, and more to introduce students to technology in learning. Mobile learning can help students access learning resources anytime and anywhere so they gain knowledge in learning that shows students' positive attitudes towards mobile learning (Marzouki, Idrissi, \& Bennani, 2017). This shows students agreed that the use of smartphones has a positive impact. Mobile technologies are the most adequate means to create an effective and efficient learning environment and positive feedback and positive attitudes show that there are positive effects on the learning process of students (Zhdanko, 2019).

Additional information obtained from the interviews was the use of smartphones increases students' knowledge. In addition, $100 \%$ of the students agreed with the idea of the use of smartphones in learning. The reasons tend to be given the ease of obtaining information. It is clear that students tend to gather information using their smartphones rather than finding information in libraries. With mobile technology, the solution is to overcome the obstacles in terms of distance in learning so that the time has come to move to a new path in educational pedagogy called mobile learning.

Students tend to discuss through their social media. Students communication skills can be improved through the use of social media. It has a positive effect on students that enables the democratization of the internet (Gusen, \& Keswet, 2017). Students tend to create discussion groups via social media to share information such as physics practice. Students realize that the basic physics practicum guides using mobile learning provide solutions for students to overcome barriers to long distance learning. Distance learning is the oldest form of 
learning that is developed into e-learning that offers new methods of distance learning based on computers and new technologies such as mobile learning. Learning using the basic physics-based practical practice guide provides opportunities for students to study anytime and anywhere because it is more practical and flexible.

The basic physics practicum guide based on mobile learning can overcome the problems experienced by students when using the print based basic physics practicum guide. Learning media that utilize online technology is able to accommodate needs whenever and wherever is real-time as the ideal learning media (Solihudin, 2018). However, the interview results show that the basic physics practicum guide based on mobile does not always meet the practical and effective aspects. This is based on their perception that $100 \%$ of students prefer to use their smartphones rather than computers to access basic physics practicum guides based on mobile learning. Apart from its size, which tends to be smaller and lighter, the display of basic physics practicum guides based on mobile learning is also interesting if accessed via a smartphone. Therefore, the basic physics practicum guide based on mobile learning can meet the indicators as a modern and sophisticated learning media when it can be accessed via a smartphone and able to facilitate the training of students' science process skills.

The basic physics practicum guide based on mobile learning is one of the learning media that can motivate students to learn. Internal motivation can be built through the regularity and intensity of the use of technology as some independent activity, even this can affect motivation in acquiring knowledge is also the motivation to achieve certain things (Irina, Anastasia, \& Elena, 2019). This was an evident from the interview where they were interested in using the basic physics practicum guide based on mobile learning so that they had no difficulty in carrying a practical guidebook which tended to be heavier when taken to the laboratory when doing basic physics practicum activities. Based on Sukmana \& Suartama research (2018), the process of teaching and learning using devices mobile learning have excellent feasibility and have a good level of interactivity and are able to make students active in practicum. Research by Pratama (2013) advocates that based mobile learning can be overcome a problem in learning activities, which is useful to facilitate, and provide ways for students to be able to understand the material explained by the lecturer. With the help of new technology, an explosion of learning and new information emerged, especially on mobile devices that is believed to be able to improve the skills and cognitive characteristics of students, the new generation, who were considered ready to work learning with technology.

\section{CONCLUSION}

This study concludes that Basic Physics Practicum Guide based on mobile learning is feasible to use for practicum. It can be seen from the positive responses given by Physics Education students and Chemistry Education students. The perception of Physics Education students towards the basic physics practicum guide based on mobile learning is better than the Chemistry Education students' perception.

It is suggested to develop learning by combining mobile learning with learning models and teaching materials appropriate to the characteristics of the material, so that the use of mobile learning can be maximized and provided supplies to the students during a practicum physics.

\section{REFERENCES}

Asrial, Syahrial., Kurniawan. D. A., Chan. F., Septianingsih. R., \&Perdana.R. (2019). Multimedia Innovation 4.0 in Education: E-Modul Ethnoconstructivism. Universal Journal of Educational Research, 7(10), 20982107 Astalini, A., Darmaji, D., Kurniawan, W., Anwar, K., \& Kurniawan, D. A. (2019). Effectivenes of Using E-Module and E- 
Assessment. International Journal of Interactive Mobile Technologies (iJIM), 13(9), 21-39.

Astalini, A., Kurniawan, D. A., Sulistiyo, U., \& Perdana, R. (2019). E-Assessment Motivation in Physics Subjects for Senior High School. International Journal of Online and Biomedical Engineering (iJOE), 15(11), 4-15.

Batubara, H. H. (2016). Penggunaan Google Form Sebagai Alat Penilaian Kinerja Dosen di Prodi PGMI Uniska Muhammad Arsyad Al Banjari. Jurnal Al Bidayah, 8(1), 39-40.

Cahyana. U, Paristiowati. M, Nurhadi. M, F \& Hasyrin.S, N. (2017). Studi Tentang Motivasi Belajar Siswa Pada Penggunaan Media Mobile Game Base Learning Dalam Pembelajaran Laju Reaksi Kimia. Jurnal Teknologi Pendidikan, 19(2), 143155.

Creswell, J. W. (2012). Educational Research: Planning, Conducting and Evaluating Quantitativ and Qualitativ Research. Lincoln: University of Nebraska.

Darmaji, D. A. Kurniawan, Astalini, A. Lumbantoruan, and S. C. Samosir. (2019). Mobile Learning in Higher Education for The Industrial Revolution 4.0 : Perception and Response of Physics Practicum. Int. J. Interact. Mob. Technol, 13(9), 4-20.

Darmaji, D. A. Kurniawan, Astalini, Kurniawan, W., Anwar. K, and A. Lumbantoruan. (2019). Students' Perceptions of Electronic's Module in Physics Practicum. Journal of Education and Learning (EduLearn), 13(2), 288294.

Darmaji, D., Kurniawan, D. A., \& Irdianti, I. (2019). Physics Education Students' Science Process Skills. International Journal of Evaluation and Research in Education, 8(2), 293-298.

Darmaji, Kurniawan, D. A., Parasdila, H., \& Irdianti. (2018). De-scription of Science Process Skills' Physics Education Students at Jambi University in
Temperature and Heat Materials. The Educational Review, USA, 2(9), 485-498. Edie, S. S., Safitri, H. N., Alighiri, D., Sari, L. M. E. K., Marwoto, P., \& Iswari, R. S. (2018). The effect of using bomb calorimeter in improving science process skills of physics students. In Journal of Physics: Conference Series, 983(1), 012205.

Gusen, J., \& Keswet, L. (2017). Opportunities and Threats of Social Media to Education: A Case Study of Undergraduate Students of the Faculty of Education, University of Jos, Nigeria. The International Journal Of Science \& Technoledge (ISSN 2321 - 919X), 5(7), 115-120.

Hasanah, I., Hasani, A., Fatah, A., Sari, I. J., \& Romdani, A. (2018). The Influence of Learning by Smartphone to the Conceptual Science Knowledge and the Independence of Students' Learning at Junior High School. Jurnal Penelitian dan Pembelajaran IPA, 4(2), 158-166.

Heinich, R, L, Molenda, J, D, Russell. (2002). Instructional Media and Technologies for Learning. New Jersey: Merril Prentice Hall.

Irina, A., Irina, B., Anastasia, G., \& Elena, D. (2019). Active Learning Technologies In Distance. International Journal of Cognitive Research in Science, Engineering and Education, 7(1), 85-94.

Kustijono, R., Jatmiko, B., \& Ibrahim, M. (2018). The Effect Of Scientific Attitudes Toward Science Process Skills In Basic Physics Practicum By Using Peer Model. International Journal Of Geomate, 15(50), 82-87.

Limatahu, N., Aulia Rahman, N., Nur Abu, S. H., \& Cipta, I. (2017). Pengaruh Video Praktikum Dengan Modul Elektronik Terhadap Keterampilan Proses Pada Materi Stoikiometri Siswa Kelas X SMAN 2 Tidore Kepulauan. Jurnal Pendidikan Kimia, 9(1), 225-228.

Maison, Darmaji, Astalini, D. A. Kurniawan, and P. S. Indrawati. (2019). Science process skills and motivation. Humanit. Soc. Sci. Rev, 7(5), 48-56. 
Maliki, A., Maksum, I., Hidayat, A., \& Sutopo, S. (2017). Kemampuan Pemecahan Masalah Siswa pada Topik Suhu dan Kalor melalui Pembelajaran Cognitive Apprenticeship. Jurnal Pendidikan: Teori, Penelitian, dan Pengembangan, 2(2), 304-308.

Marzouki, O. F., Idrissi, M. K., \& Bennani, S. (2017). Effects of Social Constructivist Mobile Learning Environments on Knowledge Acquisition: A Meta-Analysis. International Journal of Interactive Mobile Technologies (IJIM), 11(1), 18.

Misbah, M., Wati, M., \& Rif'at, M. F. (2018). Pengembangan Petunjuk Praktikum Fisika Dasar I Berbasis 5M Untuk Melatih Keterampilan Proses Sains dan Karakter Wasaka. Jurnal Fisika Flux: Jurnal Ilmiah Fisika FMIPA Universitas Lambung Mangkurat, 15(1), 26-30.

Nanda, O. A., \& Wilujeng, I. (2018). The Effectiveness of Android-assisted Optical Devices Learning to Improve Students' Conceptual Understanding. Jurnal Penelitian dan Pembelajaran IPA, 4(2), 105-115.

Ozdemir, G., \& Dikici, A. (2017). Relationships between scientific process skills and scientific creativity: Mediating role of nature of science knowledge. Journal of Education in Science Environment and Health, 3(1), 52-68.

Prasojo, Lantip Diat \& Riyant. (2011). Teknologi Informasi Pendidikan Yogyakarta: Gava Media.

Pratama, R. A., Ulfa, S., \& Kuswandi, D. (2018). Mobile Learning Berbasis Game Based Learning Pelajaran Matematika Pokok Bahasan Bangun Ruang Sisi Datar. Jurnal Pendidikan: Teori, Penelitian, dan Pengembangan, 3(6), 771-777.

Prawiradilaga, A, \& Handoko. (2013). Mozaik Pendidikan E-Learning. Yogyakarta: Gava Media.

Rahmawati, R., Handayanto, S. K., \& Dasna, I. W. (2018). Pengaruh Learning Cycle
5E terhadap Keterampilan Proses Sains Peserta Didik Kelas VIII. Jurnal Pendidikan: Teori, Penelitian, dan Pengembangan, 3(3), 286-290.

Saifuddin. M. F. (2018). E-Learning dalam Persepsi Mahasiswa. Jurnal VARIDIKA, 29(2), 102-109.

Sinaga, P., Amsor, \& Cahyanti, F. D. (2019). Effectiveness of the new generation ebook application for mobile phones in improving the conceptual mastery of kinematics. International Journal of Mobile Learning and Organisation, 13(2), 217-232.

Slameto. (2003). Belajar dan Faktor-Faktor yang Memengaruhinya. Jakarta: Rineka Cipta.

Ślusarczyk, B. (2019). Industry 4.0: are We Ready?', Polish Journal of Management Studies, 17(1), 232-248.

Solihudin, T. (2018). Pengembangan EModul Berbasis Web Untuk Meningkatkan Pencapaian Kompetensi Pengetahuan Fisika Pada Materi Listrik Statis Dan Dinamis SMA. Jurnal Wahana Pendidikan Fisika, (ISSN: 23381027), 3(2), 51-61.

Sugiyono. (2013). Metode Penelitian Pendidikan (Pendekatan Kuantitatif, Kualitatif, dan $R \& D)$. Bandung: Alfabeta.

Sukmana, A. I. W. I. Y., \& Suartama, I. K. (2018). Pengembangan Mobile Learning Berorientasi Model Pembelajaran Flipped Classroom Pada Mata Kuliah Multimedia. Journal of Education Technology, 1(2), 45-50.

Vyas, N., \& Nirban, V. (2014). Students' Perception on the Effectiveness of Mobile Learning in an Institutional Context. ELT Research Journal, 3(1), 26-36.

Wahyuni, S., \& Widiarti, N. (2010). Penerapan pembelajaran berbasis masalah berorientasi chemoentrepreneurship pada praktikum kimia fisika. Jurnal Inovasi Pendidikan Kimia, 4(1), 484-496.

Yadaeni, A., Kusairi, S., \& Parno, P. (2018). Penguasaan Konsep dan Keterampilan 
Proses Sains Siswa Kelas XII pada Materi Fluida Statis. Jurnal Pendidikan: Teori, Penelitian, dan Pengembangan, 3(3), 357-364.

Yang, Q.-F., Hwang, G.-J., \& Sung, H.-Y. (2018). Trends and research issues of mobile learning studies in physical education: a review of academic journal publications. Interactive Learning Environments, O(0), 1-19.

Young, Hugh D., Freedman, Roger A., Sandin, T. R., \& Ford, A. Lewis. (2002). Fisika Universita Edisi Kesepuluh Jilid 1. Jakarta: Erlangga.
Zhdanko, A. (2019). Identification Of Cognitive Manipulations That Have The Greatest Impact On Students In The Internet. International Journal of Cognitive Research in Science, Engineering and Education (IJCRSEE), 7(1), 35-42.

Zulika, A. M., Wijaya, M. H., Masitoh, U., Utari, S., \& Titin, T. (2018). Profil Ketrampilan Proses Sains (KPS) Siswa Dalam Menggunakan Ragam Media Pembelajaran Gerak Melingkar Di Sma. Wapfi (Wahana Pendidikan Fisika), $\quad 3(1), \quad$ 80-84. 